\title{
Effect of Forage:Concentrate Ratio on Fatty Acid Composition of Rumen Bacteria Isolated From Ruminal and Duodenal Digesta
}

\author{
B. Vlaeminck, ${ }^{*}$ V. Fievez, ${ }^{* 1}$ D. Demeyer, ${ }^{*}$ and R. J. Dewhurst $\dagger^{2}$ \\ *Laboratory for Animal Nutrition and Animal Product Quality, Ghent University, Proefhoevestraat 10, 9090 Melle, Belgium \\ †Institute of Grassland and Environmental Research, Plas Gogerddan, Aberystwyth, Ceredigion SY23 3EB, UK
}

\begin{abstract}
Four dairy cows were used to examine the effect of the dietary forage:concentrate ratio [35:65, 50:50, $65: 35$, and $80: 20$ on a dry matter (DM) basis] on the fatty acid composition of rumen bacteria isolated from the liquid (LAB) and solid (SAB) phase of the rumen and duodenal digesta. Rumen contents were sampled $4 \mathrm{~h}$ after the morning feeding. Solid and liquid phases were separated from rumen contents and duodenal bacteria from a composite duodenal sample by differential centrifugation. Total fatty acid content in bacterial DM was 1.6 to 2.8 times higher in SAB compared with LAB, and increased with dietary concentrate. In combination with published reports, the data show that bacterial fatty acid content and composition is closely related to dietary fatty acids except for C18:2n-6 and C18:3n-3. A decrease in forage:concentrate ratio increased bacterial concentration of trans-10 C18:1, and this increase was 3.4 times higher in LAB compared with SAB. Analysis of odd- and branched-chain fatty acids showed large differences between SAB and LAB, which probably reflected a difference in species composition. The variation in odd- and branched-chain fatty acids between $\mathrm{SAB}$ and $\mathrm{LAB}$ was used to estimate their relative proportions in duodenal bacteria by means of linear programming, and showed an increased proportion of $\mathrm{SAB}$ from 64.7 to $74.8 \%$ with increasing forage:concentrate ratio. In addition, increasing the proportion of dietary forage was closely related to the proportion of anteiso C15:0 in total odd- and branched-chain fatty acids $\left(\mathrm{r}_{\text {pearson }}=-0.771\right)$. The bacterial concentration of iso C17:0 closely reflected the bacterial growth rate as shown by the relation with cytosine: $\mathrm{N}\left(\mathrm{r}_{\text {pearson }}=-0.729\right)$. These strong relationships suggest that odd- and branched-chain fatty acids might be used as tool to evaluate nutrient supply to rumen bacteria.
\end{abstract}

\footnotetext{
Received September 1, 2005.

Accepted January 3, 2006.

${ }^{1}$ Corresponding author: veerle.fievez@UGent.be

${ }^{2}$ Current address: Agriculture and Life Sciences Division, Lincoln University, Canterbury, New Zealand.
}

Key words: rumen bacteria, fatty acid, odd- and branched-chain fatty acids

\section{INTRODUCTION}

The fatty acid composition of rumen bacteria is characterized by a large proportion of saturated fatty acids, mainly C16:0 and C18:0 (Katz and Keeney, 1966; Bas et al., 2003), which originate both from the uptake of dietary fatty acids and from de novo synthesis. In addition, fatty acids of rumen bacteria contain various mono- (e.g., trans-10 C18:1, trans-11 C18:1) and polyunsaturated C18 fatty acids (e.g., cis-9, trans-11 C18:2, trans-10, cis-12 C18:2, trans-11, cis-15 C18:2; Katz and Keeney, 1966; Kucuk et al., 2001; Loor et al., 2004a) derived from hydrogenation of dietary C18:2n-6 and C18:3n-3. Moreover, the fatty acid composition of rumen bacteria is characterized by a large proportion of odd- and branched-chain fatty acids (OBCFA) in their membrane lipids (pentadecanoic acid, C15:0; iso methyltetradecanoic acid, iso C15:0; anteiso methyltetradecanoic acid, anteiso C15:0; heptadecanoic acid, C17:0; iso methylhexadecanoic acid, iso $\mathrm{C} 17: 0$; and anteiso methylhexadecanoic acid, anteiso C17:0; Kaneda, 1991; Bas et al., 2003). Furthermore, bacteria seem capable of synthesizing (de novo) branched-chain fatty acids with an even chain length (mainly iso tetradecanoic acid, iso C14:0 and iso hexadecanoic acid, iso C16:0; Bas et al., 2003).

Interestingly, OBCFA patterns are of great value for the systematic differentiation of rumen bacteria (Ifkovitz and Ragheb, 1968; Miyagawa, 1982; Minato et al., 1988; Kaneda, 1991). This suggests that changes in the rumen microbial population are reflected in the OBCFA pattern of ruminal digesta (Vlaeminck et al., 2004). In addition, Keeney et al. (1962) suggested microbial OBCFA could provide a qualitative description of the proportions of different classes of microbes leaving the rumen.

The effects of lipid-supplemented diets on ruminal lipid metabolism and bacterial fatty acids are well documented (Bauchart et al., 1990; Hussein et al., 1995). Although the effect of dietary forage:concentrate ratio $(\mathbf{F}: \mathbf{C})$ on the rate of hydrogenation and the duodenal 
flow of fatty acids were previously examined (Latham et al., 1972; Kalscheur et al., 1997; Kucuk et al., 2001; Loor et al., 2004b), literature data describing the effects on the fatty acid composition of mixed rumen bacteria are scarce (Kucuk et al., 2001; Bas et al., 2003) and lacking for bacteria isolated from the liquid-associated bacteria (LAB) and solid-associated bacteria (SAB) phases of the rumen. In addition, few experiments describe the effect of diet on bacterial synthesis of OBCFA (Bas et al., 2003). Hence, to contribute to the literature data, rumen and duodenal bacteria were isolated and their fatty acid profiles determined during an experiment aimed at evaluating the effect of varying forage proportions on the efficiency of rumen $\mathrm{N}$ utilization (Moorby et al., accepted).

In the current paper, we firstly report the effect of F:C ratio on fatty acid content and composition of rumen bacteria isolated both from the liquid and solid phase of the rumen and from duodenal content. Secondly, we examined the relationship between bacterial and dietary fatty acids. For the latter purpose, data from the current experiment as well as literature data were used. In addition, OBCFA of SAB and LAB were used to i) estimate relative proportions of $\mathrm{SAB}$ and $\mathrm{LAB}$ in duodenal bacteria, and ii) illustrate shifts in the bacterial populations.

\section{MATERIALS AND METHODS}

\section{Experimental Design, Diets, and Sampling}

Experimental procedures were described previously (Moorby et al., 2006). Briefly, 4 dairy cows in midlactation with simple cannulas in the rumen (Bar-Diamond, Parma, ID) and proximal duodenum were offered diets varying in $\mathrm{F}: \mathrm{C}$ ratio, in a $4 \times 4$ Latin square. Dietary treatments were based on ad libitum access to ryegrass silage and a standard dairy concentrate with $\mathrm{F}: \mathrm{C}$ ratios of 80:20, 65:35, 50:50, and 35:65 on a DM basis (Moorby et al., 2006). Each experimental period lasted for $28 \mathrm{~d}$ of which the first $2 \mathrm{wk}$ were for adaptation. Fresh forage was offered daily at $0900 \mathrm{~h}$ and concentrates were offered twice daily in equal portions at milking ( 0800 and $1600 \mathrm{~h}$ ). The mean chemical and fatty acid composition of the grass silage and concentrate is presented in Table 1. Average daily DM intake was $13.2,15.5,18.4$, and $20.7 \mathrm{~kg}$ for diets with $\mathrm{F}: \mathrm{C}$ ratios of 80:20, 65:35, 50:50, and 35:65, respectively (Moorby et al., 2006).

Rumen and duodenal samples were taken during the final week of each experimental period. Rumen emptying was undertaken by hand $4 \mathrm{~h}$ after feeding on the final day of each period. Samples (5\%) of rumen contents were taken throughout the emptying procedure for
Table 1. Mean chemical and fatty acid composition of the grass silage and concentrate feed (mean of 8 samples of each) offered during the experiment ( $\mathrm{g} / \mathrm{kg}$ of DM unless otherwise stated)

\begin{tabular}{lcc}
\hline & Silage & Concentrate \\
\hline DM, g/kg & 264 & 876 \\
OM & 926 & 916 \\
CP & 122 & 228 \\
NDF & 619 & 248 \\
ADF & 370 & 120 \\
Water-soluble carbohydrates & 19 & 59 \\
Starch & - & 221 \\
Total fatty acids & 12.3 & 43.2 \\
C12:0 & 0.05 & 2.07 \\
C14:0 & 0.12 & 0.79 \\
C16:0 & 2.78 & 7.28 \\
C18:0 & 0.31 & 1.41 \\
cis-9 C18:1 & 0.50 & 13.0 \\
C18:2n-6 & 2.19 & 15.3 \\
C18:3n-3 & 5.52 & 2.29 \\
\hline
\end{tabular}

analysis, and rumen contents weighed and returned to all cows within 30 min of commencement. Liquidassociated bacteria were separated from rumen contents by differential centrifugation (Siddons et al., 1982). Briefly, rumen liquid (500 $\mathrm{mL}$ ) was prepared by squeezing mixed rumen contents through a plastic mesh (with 0.5 -mm diameter pores) and centrifuging the strained liquid at $1,600 \times g$ for $5 \mathrm{~min}$. The pellet was discarded, and the supernatant transferred and centrifuged at $30,000 \times g$ for $15 \mathrm{~min}$. The resultant pellet was washed twice (once with $9 \mathrm{~g} / \mathrm{L}$ saline and once with distilled water), with centrifugation at 30,000 $\times g$ for 15 min between washes. Solid-associated bacteria were isolated from rumen fiber (Merry and McAllan, 1983). Rumen fiber $(0.5 \mathrm{~kg})$ was prepared from the solid residue left after squeezing mixed rumen contents through a plastic mesh with $0.5-\mathrm{mm}$ diameter pores. The fiber was washed twice in $1.5 \mathrm{~L}$ of cold $9 \mathrm{~g} / \mathrm{L}$ saline, and squeezing through the plastic mesh after each washing. Washed fiber was divided into approximately $100-\mathrm{g}$ lots and pummeled with $320 \mathrm{~mL}$ of cold $9 \mathrm{~g} / \mathrm{L}$ saline in a Colworth stomacher (A. J. Seward and Co. Ltd., London, UK) at the "high" setting for 2 periods of 5 min each. The resultant pummeled fiber was then treated to the same series of differential centrifugation steps as described above for isolation of LAB from rumen liquid. Duodenal sampling was performed over 2 consecutive days using the automated equipment described by Evans et al. (1981), which samples for 2 to $3 \mathrm{~s}$ approximately 3 times/h. Then, duodenal bacteria were isolated from the composite sample of duodenal contents by differential centrifugation, as outlined for the LAB fraction isolated from rumen contents (Siddons et al., 1982). Bacterial samples were freeze-dried and stored frozen before analysis. 


\section{Analyses}

Bacterial samples ( $450 \mathrm{mg}$ ) were used for extraction, methylation of fatty acids, and GLC analysis of fatty acid methyl esters. Extraction and methylation of fatty acids was based on the methods described by Sukhija and Palmquist (1988). The internal standard (C23:0, $1.5 \mathrm{mg}$ ) was added before the extraction. The lipids were extracted using toluene $(0.45 \mathrm{~g}$ in $2 \mathrm{~mL})$ and transesterified to methyl esters by heating $\left(70^{\circ} \mathrm{C}\right.$ for $2 \mathrm{~h}$, under nitrogen) with $3 \mathrm{~mL}$ of methanolic $\mathrm{HCl}$. Samples were neutralized with $5 \mathrm{~mL}$ of $6 \%$ potassium carbonate, depigmented with $1 \mathrm{~g}$ of charcoal, dried with $1 \mathrm{~g}$ of anhydrous sodium sulfate, and the resultant fatty acid methyl esters analyzed by gas chromatography. Fatty acid methyl esters were analyzed by GLC (CP-3800, Varian Ltd., Walton-on-Thames, UK) using a $100 \mathrm{~m} \times$ $0.25 \mathrm{~mm}$ CP-Sil 88 column (a chemically bound stationary phase; Varian), with helium as carrier gas. The split ratio was 1:30 with the split open throughout the run. The injector and detector were held at 250 and $255^{\circ} \mathrm{C}$, respectively. A temperature gradient (starting at $70^{\circ} \mathrm{C}$, increased at $20^{\circ} \mathrm{C} / \mathrm{min}$ to $175^{\circ} \mathrm{C}$, held for 25 $\mathrm{min}$, increased at $2.5^{\circ} \mathrm{C} / \mathrm{min}$ to $200^{\circ} \mathrm{C}$, held for $2 \mathrm{~min}$, increased at $20^{\circ} \mathrm{C} / \mathrm{min}$ to $230^{\circ} \mathrm{C}$, held for $8.5 \mathrm{~min}$ ) was used to separate the fatty acid methyl esters. Fatty acid methyl esters were identified from external standards (ME61 fatty acid methyl ester mixture, Larodan Fine Chemicals AB, Malmö, Sweden; S37 Supelco 37 component FAME mix, Supelco, Poole, Dorset, UK; conjugated linoleic acids standard, Matreya, Philadelphia, PA), and quantified using the internal standard. Trans10 C18:1 was not commercially available and was identified by order of elution as described by Griinari et al. (1998). The reported temperature gradient enabled an optimized separation of $c i s-9$, trans-11 C18:2 and trans10, cis-12 C18:2. However, the reported cis-9, trans-11 C18:2 may be overestimated because of other isomers that may coelute on the gas chromatography column (trans-7, cis-9 C18:2 and trans-8, cis-10 C18:2). The increase in this peak has been considered to exclusively reflect changes in cis-9, trans-11 C18:2. Furthermore, other C18:2-isomers, besides the reported cis-9, trans$11 \mathrm{C} 18: 2$ and trans-10, cis-12 C18:2, might be present in rumen bacteria (see Kucuk et al., 2001; Loor et al., $2004 \mathrm{~b}$ ), but these are not mentioned because our analytical method has not been optimized for identification of these isomers. At the time the experiment and analysis were running, we did not dispose of the external iso C14:0 and iso C16:0 standards. Accordingly, these fatty acids were not identified in the chromatograms and are not reported in the current paper, although bacterial concentrations might be in the range of anteiso C17:0 concentrations.

\section{Data Set Derivation}

Data from 10 feeding experiments with dairy cows (Legay-Carmier and Bauchart, 1989; Bauchart et al., 1990; Klusmeyer and Clark, 1991; Tice et al., 1994; Pantoja et al., 1996; Christensen et al., 1998; Dufour et al., 2004; combined with unpublished results of B. Vlaeminck, V. Fievez, and R. J. Dewhurst) and beef steers (Hussein et al., 1995; Elliott et al., 1999) were used to examine the relationship between dietary and bacterial fatty acids. These studies were selected based on the availability in the papers of the fatty acid composition of both the diet and mixed rumen bacteria. Studies reporting fatty acid data of LAB only were discarded. Legay-Carmier and Bauchart (1989), Bauchart et al. (1990), and Dufour et al. (2004) reported fatty acid composition of both LAB and SAB. For these studies, an average fatty acid composition (50/50) was calculated from both bacterial groups. In the study by Dufour et al. (2004), OBCFA were the only bacterial fatty acids reported, although total fatty acid profiles were analyzed in these samples. Hence, data reported by Dufour et al. (2004) were completed by the other fatty acids (B. Vlaeminck, V. Fievez, and R. J. Dewhurst, unpublished data) for introduction in the current data set. In addition, mean values from the current experiment $(\mathrm{n}=$ 4) were used, resulting in an overall data set of 50 observations. Bacterial C18:3n-3, C18:2n-6, and C16:0 were related to the dietary content of these fatty acids. Bacterial monounsaturated octadecenoic fatty acids (i.e., sum of cis- and trans-C18:1 isomers) and C18:0 were related to the sum of their dietary precursors (i.e., C18:3n-3, C18:2n-6, cis-9 C18:1, and C18:0).

\section{Calculations}

Proportions of SAB and LAB in duodenal bacteria were estimated using a linear programming approach. The Solver function of Excel was used to apportion duodenal bacteria among SAB and LAB from each cow in each period according to the following equation:

$$
\text { Duodenal bacteria }\left(\mathrm{X}_{\mathrm{i}}\right)=\mathrm{A} \times \mathrm{SAB}\left(\mathrm{X}_{\mathrm{i}}\right)+\mathrm{B} \times \mathrm{LAB}\left(\mathrm{X}_{\mathrm{i}}\right)
$$

where $\mathrm{X}_{\mathrm{i}}$ are the individual OBCFA (i.e., iso C15:0, anteiso $\mathrm{C} 15: 0, \mathrm{C} 15: 0$, iso $\mathrm{C} 17: 0$, anteiso $\mathrm{C} 17: 0$, and $\mathrm{C} 17: 0)$, duodenal bacteria $\left(\mathrm{X}_{\mathrm{i}}\right), \mathrm{SAB}\left(\mathrm{X}_{\mathrm{i}}\right)$, and $\mathrm{LAB}\left(\mathrm{X}_{\mathrm{i}}\right)$ are the content of fatty acid $\mathrm{X}_{\mathrm{i}}$ in duodenal bacteria, $\mathrm{SAB}$, and $L A B$, respectively ( $\mathrm{g} / \mathrm{kg}$ of $\mathrm{DM})$, and $A$ and $B$ are the proportions of $\mathrm{SAB}$ and $\mathrm{LAB}$, respectively. The Solver function of Excel was used to minimize the sums of squares of the differences between the observed and model estimates of bacterial OBCFA. To evaluate the validity of this approach, observed and estimated 
Table 2. Effect of dietary forage:concentrate ratio (80:20, 65:35, 50:50, and 35:65) on fatty acid content (g/kg of DM) and composition of rumen bacteria $(\mathrm{g} / 100 \mathrm{~g}$ of fatty acids) isolated from the liquid (LAB) and solid $(\mathrm{SAB})$ phase of the rumen $(\mathrm{n}=4)$

\begin{tabular}{|c|c|c|c|c|c|c|c|c|c|c|c|c|}
\hline & \multicolumn{4}{|c|}{$\mathrm{SAB}$} & \multicolumn{4}{|c|}{ LAB } & SEM & \multicolumn{3}{|c|}{$P^{1}$} \\
\hline Total fatty acids & 110 & 121 & 122 & 142 & 50.3 & 56.3 & 57.8 & 66.7 & 6.50 & 0.001 & 0.003 & 0.568 \\
\hline C10:0 & 0.04 & 0.04 & 0.04 & 0.04 & 0.22 & 0.17 & 0.15 & 0.12 & 0.015 & 0.001 & 0.004 & 0.552 \\
\hline $\mathrm{C} 12: 0$ & 0.39 & 0.41 & 0.52 & 0.57 & 1.33 & 1.18 & 1.43 & 1.23 & 0.065 & 0.001 & 0.170 & 0.870 \\
\hline C14:0 & 1.46 & 1.42 & 1.46 & 1.34 & 3.60 & 3.32 & 3.23 & 2.87 & 0.157 & 0.001 & 0.020 & 0.700 \\
\hline trans-6-8 C18:1 & 0.41 & 0.43 & 0.62 & 0.67 & 0.39 & 0.53 & 0.81 & 0.98 & 0.080 & 0.014 & 0.001 & 0.823 \\
\hline trans-9 C18:1 & 0.26 & 0.38 & 0.46 & 0.53 & 0.18 & 0.27 & 0.41 & 0.47 & 0.032 & 0.028 & 0.001 & 0.439 \\
\hline trans-10 C18:1 & 0.52 & 0.57 & 0.83 & 1.20 & 0.41 & 0.66 & 1.42 & 2.29 & 0.278 & 0.074 & 0.001 & 0.250 \\
\hline trans-11 C18:1 & 5.35 & 4.98 & 4.56 & 4.82 & 2.72 & 2.86 & 2.90 & 3.45 & 0.215 & 0.001 & 0.871 & 0.107 \\
\hline trans-12 C18:1 & 0.42 & 0.55 & 0.70 & 0.79 & 0.37 & 0.51 & 0.73 & 0.86 & 0.059 & 0.754 & 0.001 & 0.807 \\
\hline trans-13-14 C18:1 & 0.54 & 0.42 & 0.56 & 0.50 & 0.47 & 0.60 & 0.84 & 0.75 & 0.067 & 0.035 & 0.021 & 0.427 \\
\hline$c i s-15 \mathrm{C} 18: 1$ & 0.28 & 0.28 & 0.23 & 0.21 & 0.22 & 0.25 & 0.18 & 0.17 & 0.014 & 0.007 & 0.001 & 0.194 \\
\hline C18:2n-6 & 1.35 & 1.52 & 2.43 & 3.05 & 2.90 & 3.55 & 4.13 & 3.57 & 0.373 & 0.004 & 0.002 & 0.479 \\
\hline cis-9, trans-11 C18:2 & 0.32 & 0.37 & 0.49 & 0.54 & 0.13 & 0.11 & 0.12 & 0.19 & 0.046 & 0.002 & 0.007 & 0.602 \\
\hline C18:3n-3 & 1.13 & 0.91 & 0.90 & 0.92 & 1.40 & 1.21 & 0.84 & 0.71 & 0.125 & 0.284 & 0.001 & 0.414 \\
\hline C20:0 & 0.98 & 0.92 & 0.81 & 0.78 & 0.63 & 0.59 & 0.54 & 0.66 & 0.037 & 0.003 & 0.012 & 0.070 \\
\hline cis-11 C20:0 & 0.16 & 0.12 & 0.15 & 0.17 & 0.07 & 0.07 & 0.11 & 0.12 & 0.013 & 0.004 & 0.014 & 0.133 \\
\hline Iso C15:0 & 1.16 & 0.97 & 0.91 & 0.71 & 3.37 & 2.62 & 2.12 & 1.67 & 0.093 & 0.001 & 0.001 & 0.297 \\
\hline Iso C17:0 & 0.40 & 0.37 & 0.32 & 0.28 & 0.66 & 0.58 & 0.65 & 0.42 & 0.049 & 0.004 & 0.003 & 0.253 \\
\hline Anteiso C15:0 & 1.85 & 1.58 & 1.57 & 1.27 & 8.38 & 7.95 & 7.82 & 5.73 & 0.520 & 0.001 & 0.009 & 0.272 \\
\hline Anteiso C17:0 & 0.56 & 0.46 & 0.40 & 0.33 & 1.27 & 1.05 & 0.88 & 0.67 & 0.044 & 0.001 & 0.001 & 0.708 \\
\hline C15:0 & 2.62 & 2.05 & 1.66 & 1.35 & 6.20 & 4.84 & 4.05 & 3.10 & 0.212 & 0.001 & 0.001 & 0.281 \\
\hline C17:0 & 0.84 & 0.70 & 0.59 & 0.52 & 1.31 & 1.30 & 0.86 & 0.71 & 0.029 & 0.001 & 0.001 & 0.014 \\
\hline
\end{tabular}

${ }^{1} P$-value for the effect of bacterial isolate (B) and the linear $(\mathrm{L})$ and quadratic $(\mathrm{Q})$ effects of the proportion of dietary forage.

(based on the $\mathrm{SAB} / \mathrm{LAB}$ proportions derived from the linear programming) duodenal fatty acid proportions were compared by the concordance correlation coefficient for all fatty acids (Lin, 1989).

\section{Statistical Analyses}

All statistical analyses were performed using SPSS 12.0 (SPSS Software for Windows, release 12.0, SPSS, Inc., Chicago, IL).

The effect of dietary treatment on fatty acid content and composition of SAB and LAB were analyzed according to

$$
\mathrm{Y}_{\mathrm{ijkl}}=\mu+\mathrm{T}_{\mathrm{i}}+\mathrm{B}_{\mathrm{j}}+\mathrm{TB}_{\mathrm{ij}}+\mathrm{C}_{\mathrm{k}}+\mathrm{BC}_{\mathrm{jk}}+\mathrm{P}_{1}+\varepsilon_{\mathrm{ijkl}}
$$

where $Y_{i j k l}$ is the individual observation, $\mu$ is the overall mean, $T_{i}$ is the effect of dietary treatment, $B_{j}$ is the effect of bacterial isolate ( $\mathrm{SAB}$ vs. $\mathrm{LAB}$ ), $\mathrm{TB}_{\mathrm{ij}}$ is the interaction between treatment and bacterial isolate, $\mathrm{C}_{\mathrm{k}}$ is the effect of cow, $\mathrm{BC}_{\mathrm{jk}}$ is the interaction between bacterial isolate and cow, $\mathrm{P}_{1}$ is the effect of experimental period, and $\varepsilon_{\mathrm{ijkl}}$ is the residual error. Effect of cow was treated as a random effect. Treatment comparisons were the linear and quadratic effect of increasing proportion of dietary forage. Treatment effects were considered significant at $P<0.05$.

The effect of dietary treatment on fatty acid content and composition of duodenal bacteria and proportion of SAB and LAB in duodenal bacteria were analyzed according to

$$
\mathrm{Y}_{\mathrm{ijk}}=\mu+\mathrm{T}_{\mathrm{i}}+\mathrm{P}_{\mathrm{j}}+\mathrm{C}_{\mathrm{k}}+\varepsilon_{\mathrm{ijk}}
$$

where $Y_{i j k}$ is the individual observation, $\mu$ is the overall mean, $T_{i}$ is the effect of dietary treatment, $P_{j}$ is the effect of experimental period, $\mathrm{C}_{\mathrm{k}}$ is the effect of cow, and $\varepsilon_{\mathrm{ijk}}$ is the residual error. Effect of cow was treated as a random effect. Treatment comparisons were the linear and quadratic effect of increasing proportion of dietary forage. Treatment effects were considered significant at $P<0.05$.

The relationship of dietary to bacterial fatty acids was evaluated using the mixed model procedure with 
the inclusion of the random effect of study as described by St-Pierre (2001). Observed bacterial fatty acids were adjusted for the study effects according to St-Pierre (2001). To avoid bias due to the incorporation of unpublished results (current study and unpublished results of B. Vlaeminck, V. Fievez, and R. J. Dewhurst) in the database, statistical analysis was performed both with and without these unpublished data. Slopes and intercepts of the equations, obtained with or without unpublished results, did not differ significantly $(P>0.5)$, which can be considered validation of the unpublished data, and justifies their incorporation in the database.

\section{RESULTS}

\section{Effect of F:C Ratio on Fatty Acid Composition of Rumen Bacteria}

$\boldsymbol{L A B}$ and $\boldsymbol{S A B}$. Fatty acid content and composition of SAB and LAB are presented in Table 2. Total fatty acid content of $\mathrm{SAB}$ was 1.6 to 2.8 times higher than that of $\mathrm{LAB}$ and decreased with increasing $\mathrm{F}: \mathrm{C}$ ratio. Diet showed no effect on proportions of the 2 major fatty acids, C16:0 and C18:0. Stearic acid was enriched in SAB, whereas C16:0 was more abundant in LAB. On a DM basis, both fatty acids were higher in SAB and increased with proportion of concentrate (data not shown). Increasing proportions of concentrate generally increased bacterial concentration of unsaturated C18fatty acids. However, cis-15 C18:1 and C18:3n-3 linearly decreased with increasing concentrate, whereas trans-11 C18:1 remained constant. Trans-6-8 C18:1 and trans-10 C18:1 increased with increasing proportion of dietary concentrate with a higher increase in LAB compared with SAB. No differences were observed in trans12 C18:1, cis-9 C18:1, and C18:3n-3 between LAB and $\mathrm{SAB}$, whereas the latter were enriched in trans-11 C18:1 and cis-9, trans-11 C18:2. Total OBCFA accounted for 5.9 and $17.0 \%$ of the fatty acids in $\mathrm{SAB}$ and $\mathrm{LAB}$, respectively, and increased with increasing proportion of dietary forage.

Duodenal Bacteria. Dietary effects induced by variation of $\mathrm{F}: \mathrm{C}$ ratio on the fatty acid content and composition of duodenal bacteria were generally in agreement with effects observed in LAB and SAB (Table 3). However, cis-9, trans-11 C18:2 in duodenal microbes was substantially lower compared with the values found in bacteria isolated from the rumen. In addition, whereas no diet effect was found for trans-11 C18:1 in bacterial isolates from the rumen, trans-11 C18:1 in duodenal microbes initially decreased as dietary forage decreased, and then increased with higher levels of concentrate, resulting in a significant quadratic effect. As shown by the dissimilarity matrix (data not shown), the fatty acid profile of duodenal bacteria was more related to the fatty acid profile of $\mathrm{SAB}$ than that of $\mathrm{LAB}$ $(P<0.001)$.

\section{Proportion of SAB and LAB in Duodenal Content}

The OBCFA pattern of SAB and LAB were used to estimate the relative proportions of both bacterial isolates in duodenal bacteria. The proportion of SAB ranged from 49.3 to $84.5 \%$, and decreased with decreasing proportion of dietary forage $(74.8,73.8,70.7$, and $64.7 \%$, for F:C ratios 80:20, 65:35, 50:50, and 35:50, respectively; $\mathrm{SEM}=1.78 ; P=0.026$ ).

Observed fatty acid composition of duodenal bacteria and fatty acid composition, as calculated from SAB and $\mathrm{LAB}$ fatty acid composition, and $\mathrm{SAB} / \mathrm{LAB}$ proportions, as estimated by linear programming, were compared by the concordance correlation coefficient. In general, observed and estimated OBCFA compositions were closely related as shown by the high concordance correlation coefficients (anteiso C15:0 $=0.946 ; \mathrm{C} 15: 0=0.936$; iso $\mathrm{C} 15: 0=0.870$; $\mathrm{C} 17: 0=0.804$; and iso $\mathrm{C} 17: 0=0.818$ ). The concordance correlation coefficients were low for C18:0 (0.150) and trans-11 C18:1 (0.231), and were moderate for anteiso C17:0 (0.533) and C18:3n-3 (0.537). Concordance correlation coefficients values for other fatty acids (i.e., C14:0, C16:0, trans-10 C18:1, cis-9 C18:1, C18:2n-6) were all higher then 0.600.

\section{Relationship of Dietary Fatty Acids with Rumen Bacterial Fatty Acids}

Relationhips between dietary fatty acids and fatty acids of rumen bacteria are presented in Figure 1. Total fatty acid content was strongly related to dietary fatty acid content (Figure 1A). In contrast, no relationship was found between dietary and bacterial C18:3n-3 ( $P=$ 0.161 ; Figure 1B), whereas bacterial C18:2n-6 was only moderately related with dietary $\mathrm{C} 18: 2 \mathrm{n}-6(P=0.081$; Figure 1C). Relationships of bacterial content ( $\mathrm{g} / \mathrm{kg}$ of DM) of C18:1 fatty acids and C18:0 and their dietary precursors were closer than for the other fatty acids (Figure 1D and 1E).

\section{DISCUSSION}

The higher fatty acid content in SAB than in LAB has also been observed by Bauchart et al. (1990) and Merry and McAllan (1983). These authors explained this difference by a higher concentration in fatty acids or microbial fatty acid precursors in the microenvironment of SAB, which can lead to increased fatty acid synthesis or incorporation of dietary fatty acids in the bacterial cells. Indeed, incorporation of dietary longchain fatty acids into bacterial cells to spare de novo 
Table 3. Effect of dietary forage:concentrate ratio (F:C) on fatty acid content (g/kg DM) and composition of rumen bacteria ( $\mathrm{g} / 100 \mathrm{~g}$ fatty acids) isolated from duodenal content $(\mathrm{n}=4)$

\begin{tabular}{|c|c|c|c|c|c|c|c|}
\hline & \multicolumn{4}{|c|}{ F:C } & \multirow[b]{2}{*}{ SEM } & \multicolumn{2}{|c|}{$P^{1}$} \\
\hline & $80: 20$ & $65: 35$ & $50: 50$ & $35: 65$ & & $\mathrm{~L}$ & Q \\
\hline Total fatty acids & 86.0 & 91.4 & 103 & 112 & 1.68 & 0.001 & 0.267 \\
\hline $\mathrm{C} 8: 0$ & 0.02 & 0.01 & 0.01 & 0.01 & 0.001 & 0.003 & 0.152 \\
\hline $\mathrm{C} 10: 0$ & 0.10 & 0.06 & 0.04 & 0.04 & 0.011 & 0.007 & 0.168 \\
\hline $\mathrm{C} 12: 0$ & 0.67 & 0.67 & 0.74 & 0.70 & 0.038 & 0.443 & 0.665 \\
\hline C14:0 & 1.97 & 1.99 & 1.74 & 1.62 & 0.061 & 0.003 & 0.291 \\
\hline C16:0 & 19.9 & 19.9 & 19.2 & 19.0 & 0.21 & 0.017 & 0.664 \\
\hline cis-9 C16:1 & 0.18 & 0.18 & 0.14 & 0.14 & 0.015 & 0.052 & 0.930 \\
\hline C18:0 & 51.2 & 52.2 & 54.4 & 53.9 & 0.73 & 0.020 & 0.380 \\
\hline trans-6-8 C18:1 & 0.37 & 0.46 & 0.54 & 0.64 & 0.030 & 0.001 & 0.760 \\
\hline trans-9 C18:1 & 0.20 & 0.26 & 0.34 & 0.44 & 0.016 & 0.001 & 0.280 \\
\hline trans-10 C18:1 & 0.45 & 0.56 & 0.75 & 0.97 & 0.081 & 0.003 & 0.532 \\
\hline trans-11 C18:1 & 4.38 & 3.95 & 3.86 & 4.41 & 0.104 & 0.995 & 0.003 \\
\hline trans-12 C18:1 & 0.40 & 0.51 & 0.63 & 0.82 & 0.038 & 0.001 & 0.357 \\
\hline trans-13-14 C18:1 & 0.38 & 0.39 & 0.46 & 0.36 & 0.009 & 0.958 & 0.001 \\
\hline trans-15 C18:1 & 0.51 & 0.57 & 0.67 & 0.79 & 0.030 & 0.001 & 0.331 \\
\hline$c i s-9 \mathrm{C} 18: 1$ & 2.72 & 3.22 & 3.48 & 4.30 & 0.078 & 0.001 & 0.087 \\
\hline cis-11 C18:1 & 0.72 & 0.74 & 0.76 & 0.77 & 0.022 & 0.191 & 0.838 \\
\hline cis-12 C18:1 & 0.23 & 0.30 & 0.37 & 0.46 & 0.027 & 0.001 & 0.779 \\
\hline cis-13 C18:1 & 0.04 & 0.04 & 0.04 & 0.05 & 0.003 & 0.067 & 0.765 \\
\hline cis-15 C18:1 & 0.29 & 0.30 & 0.24 & 0.21 & 0.016 & 0.005 & 0.318 \\
\hline C18:2n-6 & 1.82 & 2.09 & 2.24 & 2.55 & 0.083 & 0.001 & 0.827 \\
\hline cis -9, trans-11 C18:2 & 0.02 & 0.02 & 0.02 & 0.02 & 0.001 & 0.017 & 0.113 \\
\hline C18:3n-3 & 1.13 & 0.96 & 0.73 & 0.62 & 0.036 & 0.001 & 0.399 \\
\hline $\mathrm{C} 20: 0$ & 0.87 & 0.81 & 0.77 & 0.71 & 0.016 & 0.001 & 0.789 \\
\hline cis-11 C20:0 & 0.06 & 0.07 & 0.08 & 0.09 & 0.004 & 0.001 & 0.451 \\
\hline Iso C15:0 & 1.85 & 1.63 & 1.31 & 1.00 & 0.040 & 0.001 & 0.303 \\
\hline Iso C17:0 & 0.58 & 0.51 & 0.42 & 0.33 & 0.016 & 0.001 & 0.624 \\
\hline Anteiso C15:0 & 3.39 & 3.19 & 2.62 & 2.23 & 0.106 & 0.001 & 0.398 \\
\hline Anteiso C17:0 & 0.95 & 0.76 & 0.64 & 0.50 & 0.012 & 0.001 & 0.071 \\
\hline $\mathrm{C} 15: 0$ & 3.42 & 2.81 & 2.00 & 1.60 & 0.097 & 0.001 & 0.288 \\
\hline C17:0 & 1.10 & 0.85 & 0.69 & 0.59 & 0.015 & 0.001 & 0.003 \\
\hline
\end{tabular}

${ }^{1} P$-value for the linear (L) and quadratic (Q) effects of the proportion of dietary forage.

synthesis (Demeyer et al., 1978) has been suggested in earlier studies in which long-chain fatty acid composition of ruminal bacteria reflected the types of dietary fat (Bauchart et al., 1990). In addition, the higher fatty acid content of SAB could be related to a lower proportion of gram-positive bacteria, because bacterial fatty acids are mainly associated with the bacterial cell wall, and fatty acid concentration in the cell wall is markedly lower in gram-positive than in gram-negative bacteria. The latter finding may explain the higher content in LAB of branched-chain fatty acids, known to be mainly associated with gram-positive bacteria (Kaneda, 1991).

\section{Incorporation of Dietary Fatty Acids}

An increase in fatty acid content with an increasing proportion of concentrate in rumen bacteria is in accordance with results from Czerkawski (1976) who stated that the increase in bacterial fatty acid content was linked to an increase in dietary concentrate due to its higher lipid content. Combining current experimental and literature data showed that an increase in dietary fatty acids of $10 \mathrm{~g} / \mathrm{kg}$ of DM results in an increased bacterial fatty acid content of $8.06 \mathrm{~g} / \mathrm{kg}$ of DM (Figure 1A). It is not known whether this increase results from incorporation or physical adsorption on the cell envelope of fatty acids. However, incorporation is a process certainly to be considered because removal of fatty acids through washing the cells with hexane or sodium hydroxide was not successful (Harfoot et al., 1974). Indeed, Bauchart et al. (1990) reported incorporation by bacteria of fatty acids as intracellular lipid droplets, whereas others showed a significant proportion of radioactive C18:2n-6 and C18:3n-3 to be incorporated into bacterial polar lipids (Hawke, 1971; Demeyer et al., 1978). However, the current study, combined with some published data, shows that bacterial C18:3n-3 and C18:2n-6 contents is not related or is only moderately related to dietary C18:3n-3 and C18:2n-6. Because the anaerobic pathway of bacterial fatty acid biosynthesis is not capable of introducing more than one double bond per fatty acid (Russell and Nichols, 1999), it is suggested that rumen bacteria readily incorporate $\mathrm{C} 18: 2 \mathrm{n}$ 6 and C18:3n-3 up to 3.06 and $1.12 \mathrm{~g} / \mathrm{kg}$ of DM, respec- 

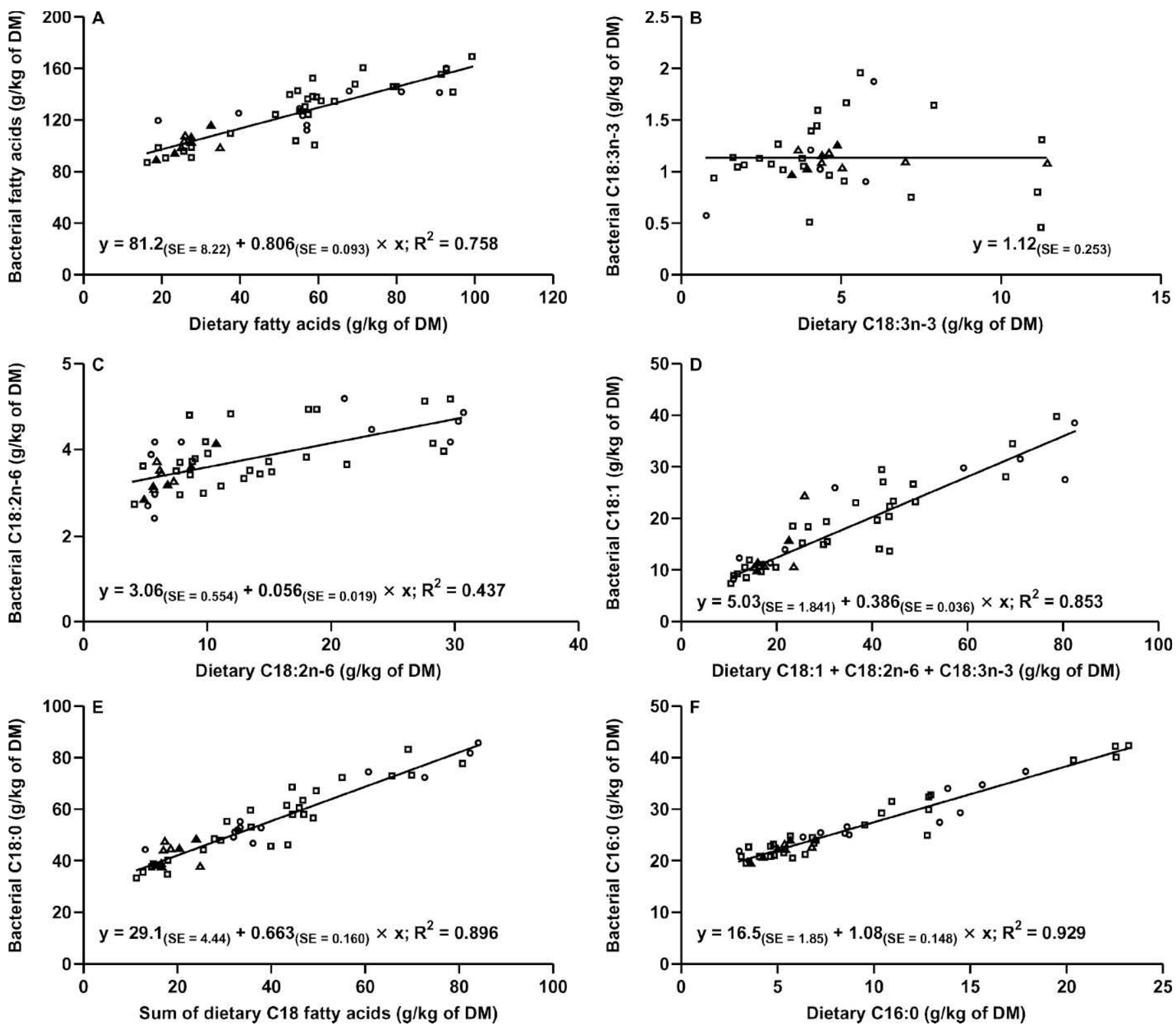

Figure 1. Relationship between bacterial content of fatty acids and dietary fatty acids ( $\mathrm{g} / \mathrm{kg}$ of $\mathrm{DM})$ based on results from the present experiment $(\boldsymbol{\Delta} ; \mathrm{n}=4)$, unpublished data from B. Vlaeminck, V. Fievez, and R. J. Dewhurst $(\Delta ; \mathrm{n}=6)$, and published data ( $\mathrm{n}=40)$ of rumen bacteria isolated from the rumen of dairy cows ( $\square$; Legay-Carmier and Bauchart, 1989; Bauchart et al., 1990; Klusmeyer and Clark, 1991; Tice et al., 1994; Pantoja et al., 1996; Christensen et al., 1998) and beef steers (O; Hussein et al., 1995; Elliott et al., 1999). Sum of dietary C18-fatty acids: C18:0 + C18:1 + C18:2n-6 + C18:3n-3; C18:1: sum of cis- and trans-C18:1 isomers.

tively (Figure 1, panels B and C). These results are in agreement with the findings of Bauchart et al. (1990), who stated that rumen bacteria preferentially and proportionally incorporate C18:2n-6 over C18:3n-3. This finding may help to partially explain the well-known higher rate of hydrogenation observed for C18:3n-3 vs. C18:2n-6.

Demeyer et al. (1978) showed part of the radioactivity of C18:2n- 6 to be recovered in monounsaturated C18 fatty acids in the bacterial phospholipid fraction, sug- gesting that hydrogenated fatty acids are incorporated. This might explain the increasing proportion of trans$10 \mathrm{C} 18: 1$ in rumen bacteria with low F:C ratio. Indeed, the increase in rumen trans-10 C18:1 with decreasing $\mathrm{F}: \mathrm{C}$ is consistent with previous reports reviewed by Bauman and Griinari (2003), in which high-grain diets shifted the hydrogenation pathway of C18:2n-6 away from cis-9, trans-11 C18:2 and trans-11 C18:1 toward trans-10, cis-12 C18:2 and trans-10 C18:1. Increasing proportions of concentrate increased the ratio trans -10 


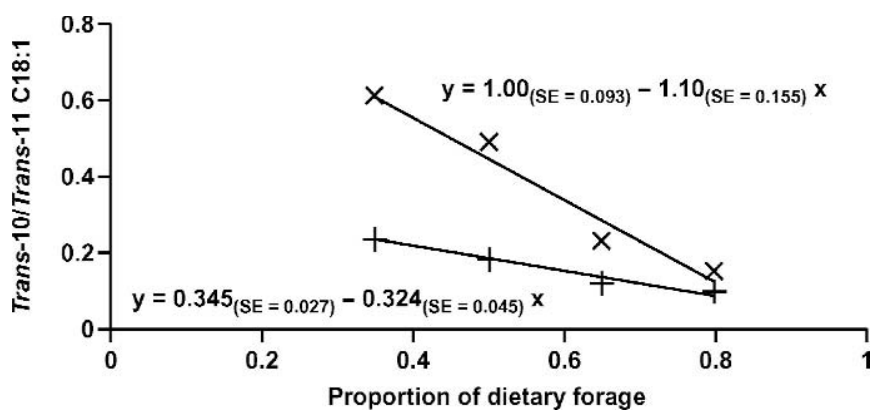

Figure 2. Effect of proportion of dietary forage on the ratio of trans-10 $\mathrm{C}_{18: 1}$ to trans-11 $\mathrm{C}_{18: 1}$ in rumen bacteria isolated from the liquid $(\times)$ and solid phase of the rumen $(+)$.

C18:1 to trans-11 C18:1 in $\mathrm{LAB}$ and $\mathrm{SAB}$, and this increase was 3.4 times higher in LAB than in $\mathrm{SAB}$ (Figure 2). Recently, Kim et al. (2002) found that LAB produced more trans-10, cis-12 C18:2 when they were incubated with C18:2n-6 compared with SAB; even higher productions were observed when LAB were isolated from cattle fed a grain-based diet. The results suggest that the abundance of rumen bacteria capable of producing trans-10, cis-12 C18:2 and trans-10 C18:1 is higher in LAB compared with $\mathrm{SAB}$ and increases both in $\mathrm{SAB}$ and $\mathrm{LAB}$ with increasing proportion of dietary concentrate. However, no significant quantities of trans-10, cis-12 C18:2 were found in SAB and LAB. Loor et al. (2004a) found no differences in the concentration of trans-10, cis-12 C18:2 between SAB and LAB $(0.1 \mathrm{~g} / 100 \mathrm{~g}$ of fatty acids). It is possible that trans-10, cis-12 C18:2 is produced in the extracellular matrix around bacteria, but not extensively incorporated as was suggested for cis-9, trans-11 C18:2 (Kim et al., 2005). Recent in vitro research demonstrated that oleic acid could be isomerized to several trans $\mathrm{C} 18: 1$ isomers (Mosley et al., 2002; AbuGhazaleh et al., 2005). It is possible that isomerization of cis-9 C18:1, rather than hydrogenation of trans-10, cis-12 C18:2, was responsible for the higher bacterial concentration of trans-10 C18:1 with higher dietary proportions of concentrate. Nevertheless, AbuGhazaleh et al. (2005) found that trans monoene isomers, derived from oleic acid, showed a double bond primarily at positions $\mathrm{C} 7, \mathrm{C} 9$, and $\mathrm{C} 14$. Moreover in these in vitro studies, more than $75 \%$ of trans-10 C18:1 was derived from the hydrogenation of C18:2n-6, which accounted for only $9 \%$ of the dietary fatty acids. In the current experiment, C18:2n-6 represented more than $25 \%$ of the dietary fatty acids. Consequently, it is unlikely that a major part of the bacterial trans-10 C18:1 was derived from the isomerization of cis-9 C18:1 rather than the hydrogenation of C18:2n6. Nevertheless, the increased intake in both dietary cis-9 C18:1 and C18:2n-6 with decreasing F:C ratio makes it difficult to distinguish between the isomerization of cis-9 C18:1 or hydrogenation of trans-10, cis$12 \mathrm{C} 18: 2$ as the main factor driving bacterial trans$10 \mathrm{C} 18: 1$.

In the current experiment, the bacterial concentration of cis-9, trans-11 C18:2 was, on average, 0.43 and $0.14 \mathrm{~g} / 100 \mathrm{~g}$ of fatty acids for $\mathrm{SAB}$ and LAB, respectively. Loor et al. (2004a) found similar values for SAB $(0.3 \mathrm{~g} / 100 \mathrm{~g}$ of fatty acids) and LAB $(0.1 \mathrm{~g} / 100 \mathrm{~g}$ of fatty acids). These values are higher than the values reported by Kim et al. (2005) in SAB (0.04 g/100 g of fatty acids) and LAB (0.06 g/100 $\mathrm{g}$ of fatty acids) and duodenal bacteria in the current experiment. Contamination of the bacterial fraction isolated from the rumen with protozoa might explain the higher concentration of cis-9, trans-11 C18:2 because protozoa are relatively enriched in cis-9, trans-11 C18:2 (Devillard et al., 2004). Nevertheless, the reason for the large differences in bacterial concentration of cis-9, trans-11 C18:2 is probably related to other factors. Indeed, if the bacterial sample isolated from the rumen was contaminated with protozoa, we would expect a lower fatty acid content because the fatty acid content of protozoa ( $23 \mathrm{~g} / \mathrm{kg}$ of DM; Weisbjerg et al., 1992) is much lower compared with SAB (90 to $159 \mathrm{~g} / \mathrm{kg}$ of DM; Bauchart et al., 1990; Loor et al., 2004a; Kim et al., 2005) and LAB (36 to $71 \mathrm{~g} / \mathrm{kg} \mathrm{DM}$; Bauchart et al., 1990; Loor et al., 2004a; Kim et al., 2005). Recently, we found that $S A B$ and LAB showed lower concentrations of cis-9, trans-11 C18:2 prefeeding than $4 \mathrm{~h}$ after feeding (B. Vlaeminck, V. Fievez, and R. J. Dewhurst, unpublished results). This might explain the differences observed in concentrations of cis-9, trans-11 C18:2 between bacteria isolated from the rumen and duodenum. Indeed, rumen bacteria were isolated $4 \mathrm{~h}$ after feeding, whereas duodenal bacteria were collected over a longer period. However, Kim et al. (2005) found no significant effect of sampling time on bacterial fatty acid concentrations. Finally, one could argue that this difference may also partly be attributable to the sampling site of the digesta due to acidic isomerization of the double bonds induced by gastric acid in the abomasum, which would result in the conversion of cis-trans to trans-trans isomers (Shingfield et al., 2003). Nevertheless, Lee et al. (2005) suggested that abomasal acidic conditions resulted in minimal isomerization.

\section{Bacterial OBCFA}

Microbial odd-chain fatty acids (C15:0 and C17:0) are formed through elongation of propionate or valerate, whereas precursors of branched-chain fatty acids (iso $\mathrm{C} 14: 0$, iso $\mathrm{C} 15: 0$, iso $\mathrm{C} 16: 0$, iso $\mathrm{C} 17: 0$, anteiso $\mathrm{C} 15: 0$, anteiso $\mathrm{C} 17: 0)$ are branched-chain amino acids (valine, 
leucine, and isoleucine) and their corresponding branched short-chain carboxylic acids (isobutyric, isovaleric, and 2-methyl butyric acids; Kaneda, 1991). Although the OBCFA profile of many cultivable rumen bacteria has been reported (Ifkovitz and Ragheb, 1968; Minato et al., 1988; Miyagawa, 1982), only a limited number of selected species have been studied and it is not feasible to attempt to describe the species composition of rumen samples from the OBCFA profile. Nevertheless, such noncultural techniques, based on the analysis of bacterial lipids, offer the prospect of detecting shifts in the rumen microbial ecology in response to, for example, dietary shifts (Dehority and Orpin, 1988). Differences between SAB and LAB in chemical composition (Merry and McAllan, 1983) and enzyme activity (Williams and Strachan, 1984; Michalet-Doreau et al., 2001) demonstrate that the distribution of bacterial species is different in the liquid and solid phases of the rumen (Michalet-Doreau et al., 2001). This is in agreement with the current analysis of OBCFA, which suggests that the species composition of the adherent population differs from that of the liquid phase. The higher concentration of anteiso C15:0 in LAB is in agreement with results reported by Dufour et al. (2004) and Kim et al. (2005). Although total concentration of OBCFA decreased with decreasing $\mathrm{F}: \mathrm{C}$, a lower proportion of dietary concentrate decreased the proportion of anteiso C15:0 in total OBCFA in duodenal bacteria. Recently, Bas et al. (2003) found a similar decrease in the relative abundance of anteiso C15:0 in total OBCFA in rumen bacteria when goats were fed decreasing proportions of concentrate. Combining the results reported by Bas et al. (2003) with the results of the current experiment indicated that the forage proportion was strongly related to the concentration of anteiso C15:0 in total OBCFA ( $\mathrm{r}_{\text {pearson }}=(0.771, P=0.009, \mathrm{n}=10)$. Decreasing F:C ratios also linearly reduced iso C15:0. Although not measured in the current study, a similar effect might be expected on the iso $\mathrm{C} 14: 0$ and iso $\mathrm{C} 16: 0$ proportions, because a strong correlation $\left(\mathrm{R}^{2}=0.97\right.$ to 0.98 ) has been observed between proportions of iso fatty acids with a chain length of 14 to 16 carbons in mixed rumen bacteria (Bas et al., 2003). In the latter study, reporting the fatty acid composition of mixed rumen bacteria, amounts of iso C14:0 and iso C16:0 were about 43 and 54\%, respectively, of the $i$ so $\mathrm{C} 15: 0$ concentration.

Increasing the $\mathrm{F}: \mathrm{C}$ ratio is usually beneficial for the pool of SAB because more fibrolytic bacteria attach to forage particles (Weimer et al., 1999). Indeed, the estimated proportion of SAB increased from 64.7 to $74.8 \%$ with increasing proportion of dietary forage. Faichney (1980) reported that the proportion of SAB in the rumen reached $90 \%$ in sheep fed roughage only, whereas it declined to $50 \%$ for steers fed equal proportions of forage and concentrate (Merry and McAllan, 1983). Increasing proportions of $\mathrm{SAB}$ with increasing $\mathrm{F}: \mathrm{C}$ might reflect both the increased attachment to forage particles (Weimer et al., 1999) as well as a decreased growth rate of LAB by substrate limitation (Bates et al., 1985). Indeed, the decreased ratio of cytosine: $\mathrm{N}$ in $\mathrm{LAB}(0.070$, $0.064,0.057$, and 0.055 for F:C of 36:65, 50:50, 65:35, and 80:20, respectively; SEM $=0.003 ; P=0.009)$ and adenine: $\mathrm{N}(0.095,0.091,0.081$, and 0.081 for $\mathrm{F}: \mathrm{C}$ of $36: 65$, 50:50, 65:35, and 80:20, respectively; SEM = $0.002 ; P=0.003$ ) with increasing $\mathrm{F}: \mathrm{C}$ suggests a decreased growth rate of LAB under these circumstances (Bates et al., 1985). In addition, these ratios also suggest a lower growth rate of SAB (0.043 and 0.059 for cytosine: $\mathrm{N}$ and adenine: $\mathrm{N}$, respectively) compared with LAB, which was not affected by dietary treatment $(P$ $>0.20$ ). These findings are in line with the results reported by Bates et al. (1985). Interestingly, bacterial growth rate showed a strong negative relationship with bacterial concentration of iso C17:0 ( $\mathrm{r}_{\text {pearson }}=-0.729$ and -0.823 for cytosine: $\mathrm{N}$ and adenine: $\mathrm{N}$, respectively, $P<0.001, \mathrm{n}=32$ ).

The changes in anteiso $\mathrm{C} 15: 0$ and iso $\mathrm{C} 17: 0$ were probably a reflection of the shifts in the bacterial population. In general, increasing the concentrate proportion increases the relative importance of amylolytic bacteria (e.g., Prevotella ruminicola, Ruminobacter amilophilus, Succinivibrio dextrinosolvens; Dehority and Orpin, 1988), which are enriched in anteiso C15:0 (Ifkovitz and Ragheb, 1968; Minato et al., 1988; Miyagawa, 1982). Similarly, the cellulolytic bacteria Ruminococcus flavefaciens and Butyrivibrio fibrisolvens are enriched in iso C17:0, whereas the amylolytic bacteria Selenomonas ruminantium, Ruminobacter amilophilus, and Succinivibrio dextrinosolvens contain little iso C17:0 (Ifkovitz and Ragheb, 1968; Minato et al., 1988; Miyagawa, 1982). Hence, the results suggest LAB are enriched in amylolytic bacteria and show a higher growth rate compared with SAB. However, the high abundance of anteiso C15:0 in some strains of the cellulolytic bacteria Butyrivibrio fibrisolvens and the low content of this fatty acid in Selenomonas ruminantium as well as the high content of iso C17:0 in some strains of Prevotella ruminicola (Ifkovitz and Ragheb, 1968; Minato et al., 1988; Miyagawa, 1982) illustrates the difficulty in describing the bacterial composition of rumen samples at the species level based on the OBCFA profile. Nevertheless, the strong relationships suggest that OBCFA, in particular anteiso C15:0 and iso C17:0, might be used as a tool to evaluate nutrient supply to rumen bacteria.

\section{CONCLUSIONS}

Variation in the dietary $\mathrm{F}: \mathrm{C}$ ratio altered the fatty acid content and composition of rumen bacteria isolated 
from the liquid and solid phases of the rumen and from duodenal contents. Although bacterial and dietary content of C18:2n-6 and C18:3n-3 were poorly related, the results suggest that rumen bacteria preferentially and proportionally incorporate $\mathrm{C} 18: 2 \mathrm{n}-6$ more than they do C18:3n-3. The higher increase in trans-10 C18:1 in LAB compared with $\mathrm{SAB}$ and associated with a decreased $\mathrm{F}: \mathrm{C}$ ratio suggests a higher abundance in LAB of bacteria capable of producing trans-10 C18:1.

Analysis of OBCFA suggested the presence of different bacterial populations in the solid and liquid phases of the rumen. Using this variation in the OBCFA pattern, relative proportions of both bacterial fractions in duodenal bacteria could be estimated by linear programming, and showed that increasing $\mathrm{F}: \mathrm{C}$ increased relative proportions of $\mathrm{SAB}$ in duodenal bacteria. In addition, the strong relationship of anteiso $\mathrm{C} 15: 0$ and iso $\mathrm{C} 17: 0$ with the dietary proportion of forage and bacterial growth rate, respectively, suggests that OBCFA might be used as tool to evaluate nutrient supply to rumen bacteria.

\section{ACKNOWLEDGMENTS}

The Ph.D. research of Bruno Vlaeminck is supported by the Institute for the Promotion of Innovation through Science and Technology in Flanders. This work was funded by the UK Ministry of Agriculture, Fisheries and Food (now Department for Environment, Food and Rural Affairs).

\section{REFERENCES}

AbuGhazaleh, A. A., M. B. Riley, E. E. Thies, and T. C. Jenkins. 2005. Dilution rate and $\mathrm{pH}$ effects on the conversion of oleic acid to trans C18:1 positional isomers in continuous culture. J. Dairy Sci. 88:4334-4341.

Bas, P., H. Archimède, A. Rouzeau, and D. Sauvant. 2003. Fatty acid composition of mixed-rumen bacteria: Effect of concentration and type of forage. J. Dairy Sci. 86:2940-2948.

Bates, D. B., J. A. Gillett, S. A. Barao, and W. G. Bergen. 1985. The effect of specific growth rate and stage of growth on nucleic acidprotein values of pure cultures and mixed ruminal bacteria. J. Anim. Sci. 61:713-724.

Bauchart, D., F. Legay-Carmier, M. Doreau, and B. Gaillard. 1990. Lipid metabolism of liquid-associated and solid-adherent bacteria in rumen contents of dairy cows offered lipid-supplemented diets. Br. J. Nutr. 63:563-578.

Bauman, D. E., and J. M. Griinari. 2003. Nutritional regulation of milk fat synthesis. Annu. Rev. Nutr. 23:203-227.

Christensen, R. A., J. H. Clark, J. K. Drackley, and S. A. Blum. 1998. Fatty acid flow to the duodenum and in milk from cows fed diets that contained fat and nicotinic acid. J. Dairy Sci. 81:1078-1088.

Czerkawski, J. W. 1976. Chemical composition of microbial matter in the rumen. J. Sci. Food Agric. 27:621-632.

Dehority, B. A., and C. G. Orpin. 1988. Development of, and natural fluctuations in, rumen microbial populations. Pages 151-183 in The Rumen Microbial Ecosystem. P. N. Hobson, ed. Elsevier Science Publishers, London, UK.

Demeyer, D. I., C. Henderson, and R. A. Prins. 1978. Relative significance of exogenous and de novo synthesized fatty acids in forma- tion of rumen microbial lipids in vitro. Appl. Environ. Microbiol. 35:24-31.

Devillard, E., F. M. McIntosh, K. Young, M. Castet, R. J. Wallace, and C. J. Newbold. 2004. Conjugated linoleic acid composition of rumen bacterial and protozoal populations. Reprod. Nutr. Dev. 44(Suppl. 1):S60. (Abstr.)

Dufour, C., B. Vlaeminck, T. Van Nespen, R. Dewhurst, and V. Fievez. 2004. Characteristic odd and branched-chain fatty acids of solidand liquid-associated rumen bacteria. Reprod. Nutr. Dev. 44(Suppl. 1):S62. (Abstr.)

Elliott, J. P., J. K. Drackley, A. D. Beaulieu, C. G. Aldrich, and N. R. Merchen. 1999. Effects of saturation and esterification of fat sources on site and extent of digestion in steers: Digestion of fatty acids, triglycerides, and energy. J. Anim. Sci. 77:1919-1929.

Evans, R. T., K. V. Skelton, and D. E. Beever. 1981. Portable equipment for the automatic sampling of duodenal contents from housed or grazing cattle. Lab. Pract. 30:997-1000.

Faichney, G. J. 1980. Measurement in sheep of the quantity and composition of rumen digesta and of the fractional outflow rates of digesta constituents. Aust. J. Agric. Res. 31:1129-1137.

Griinari, J. M., D. A. Dwyer, M. A. McGuire, D. E. Bauman, D. L. Palmquist, and K. V. V. Nurmela. 1998. Trans-octadecenoic acids in milk fat depression in lactating dairy cows. J. Dairy Sci. 81:1251-1261.

Harfoot, C. G., M. L. Crouchman, R. C. Noble, and J. H. Moore. 1974. Competition between food particles and rumen bacteria in the uptake of long-chain fatty acids and triglycerides. J. Appl. Bacteriol. 37:633-641.

Hawke, J. C. 1971. The incorporation of long-chain fatty acids into lipids by rumen bacteria and the effect on biohydrogenation. Biochim. Biophys. Acta 248:167-170.

Hussein, H. S., N. R. Merchen, and G. C. Fahey, Jr. 1995. Composition of ruminal bacteria harvested from steers as influenced by dietary forage level and fat supplementation. J. Anim. Sci. 73:2469-2473.

Ifkovitz, R. W., and H. S. Ragheb. 1968. Cellular fatty acid composition and identification of rumen bacteria. Appl. Microbiol. 16:1406-1413.

Kalscheur, K. F., B. B. Teter, L. S. Piperova, and R. A. Erdman. 1997. Effect of dietary forage concentration and buffer addition on duodenal flow of trans-C18:1 fatty acids and milk fat production in dairy cows. J. Dairy Sci. 80:2104-2114.

Kaneda, T. 1991. Iso- and anteiso-fatty acids in bacteria: Biosynthesis, function, and taxonomic significance. Microbiol. Rev. 55:288-302.

Katz, I., and M. Keeney. 1966. Characterization of the octadecenoic acids in rumen digesta and rumen bacteria. J. Dairy Sci. 49:962-966.

Keeney, M., I. Katz, and M. J. Allison. 1962. On the probable origin of some milk fat acids in rumen microbial lipids. J. Am. Oil Chem. Soc. 39:198-201.

Kim, E. J., R. Sanderson, M. S. Dhanoa, and R. J. Dewhurst. 2005. Fatty acid profiles associated with microbial colonization of freshly ingested grass and rumen biohydrogenation. J. Dairy Sci. 88:3220-3230.

Kim, Y. J., R. H. Liu, J. L. Rychlik, and J. B. Russell. 2002. The enrichment of a ruminal bacterium (Megasphaera elsdenii YJ-4) that produces the trans-10, cis-12 isomer of conjugated linoleic acid. J. Appl. Microbiol. 92:976-982.

Klusmeyer, T. H., and J. H. Clark. 1991. Effects of dietary fat and protein on fatty acid flow to the duodenum and in milk produced by dairy cows. J. Dairy Sci. 74:3055-3067.

Kucuk, O., B. W. Hess, P. A. Ludden, and D. C. Rule. 2001. Effect of forage:concentrate ratio on ruminal digestion and duodenal flow of fatty acids in ewes. J. Anim. Sci. 79:2233-2240.

Latham, M. J., J. E. Storry, and M. E. Sharpe. 1972. Effects of lowroughage diets on the microflora and lipid metabolism in the rumen. Appl. Microbiol. 24:871-877.

Lee, M. R. F., J. K. S. Tweed, A. P. Moloney, and N. D. Scollan. 2005. The effects of fish oil supplementation on rumen metabolism and the biohydrogenation of unsaturated fatty acids in beef steers given diets containing sunflower oil. Anim. Sci. 80:361-367. 
Legay-Carmier, F., and D. Bauchart. 1989. Distribution of bacteria in the rumen contents of dairy-cows given a diet supplemented with soybean oil. Br. J. Nutr. 61:725-740.

Lin, L. I. 1989. A concordance correlation-coefficient to evaluate reproducibility. Biometrics 45:255-268.

Loor, J. J., K. Ueda, A. Ferlay, Y. Chilliard, and M. Doreau. 2004a. Trans fatty acids (tFA) and CLA in liquid-associated (LAB) and solid-adherent $(\mathrm{SAB})$ ruminal bacteria from dairy cows fed diets varying in forage:concentrate ratio (F:C) and level of linseed, sunflower, or fish oil. J. Dairy Sci. 81(Suppl. 1):272. (Abstr.)

Loor, J. J., K. Ueda, A. Ferlay, Y. Chilliard, and M. Doreau. 2004b. Biohydrogenation, duodenal flows, and intestinal digestion of trans fatty acids and conjugated linoleic acids in response to dietary forage:concentrate ratio and linseed oil in dairy cows. J. Dairy Sci. 87:2472-2485.

Merry, R. J., and A. B. McAllan. 1983. A comparison of the chemical composition of mixed bacteria harvested from the liquid and solid fractions of rumen digesta. Br. J. Nutr. 50:701-709.

Michalet-Doreau, B., I. Fernandez, C. Peyron, L. Millet, and G. Fonty. 2001. Fibrolytic activities and cellulolytic bacterial community structure in the solid and liquid phases of rumen contents. Reprod. Nutr. Dev. 41:187-194.

Minato, H., S. Ishibashi, and T. Hamaoka. 1988. Cellular fatty acid and sugar composition of representative strains of rumen bacteria. J. Gen. Appl. Microbiol. 34:303-319.

Miyagawa, E. 1982. Cellular fatty acid and fatty aldehyde composition of rumen bacteria. J. Gen. Appl. Microbiol. 28:389-408.

Moorby, J. M., R. J. Dewhurst, R. T. Evans, and J. Danelón. 2006. Effects of diet forage proportion on microbial yield from the rumen. 1. Milk production, duodenal purines and urinary purine derivatives. J. Dairy Sci. 89: (accepted)

Mosley, E. E., G. L. Powell, M. B. Riley, and T. C. Jenkins. 2002. Microbial biohydrogenation of oleic acid to trans isomers in vitro. J. Lipid Res. 43:290-296.
Pantoja, J., J. L. Firkins, M. L. Eastridge, and B. H. Hull. 1996. Fatty acid digestion in lactating dairy cows fed fats varying in degree of saturation and different fiber sources. J. Dairy Sci. 79:575-584.

Russell, N. J., and D. S. Nichols. 1999. Polyunsaturated fatty acids in marine bacteria-A dogma rewritten. Microbiology 145:767-779.

Shingfield, K., S. Ahvenjärvi, V. Toivonen, A. Ärölä, K. V. V. Nurmela, P. Huhtanen, and J. Griinari. 2003. Effect of dietary fish oil on biohydrogenation of fatty acids and milk fatty acid content in cows. Anim. Sci. 77:165-179.

Siddons, R. C., D. E. Beever, and J. V. Nolan. 1982. A comparison of methods for the estimation of microbial nitrogen in duodenal digesta of sheep. Br. J. Nutr. 48:377-389.

St-Pierre, N. R. 2001. Invited review: Integrating quantitative findings from multiple studies using mixed model methodology. J. Dairy Sci. 84:741-755.

Sukhija, P. S., and D. L. Palmquist. 1988. Rapid method for the determination of total fatty acid content and composition of feedingstuffs and feces. J. Agric. Food Chem. 36:1202-1206.

Tice, E. M., M. L. Eastridge, and J. L. Firkins. 1994. Raw soybeans and roasted soybeans of different particle sizes. 2. Fatty acid utilization by lactating cows. J. Dairy Sci. 77:166-180.

Vlaeminck, B., V. Fievez, H. van Laar, and D. Demeyer. 2004. Prediction of rumen volatile fatty acid proportions produced in vitro using variations in rumen odd and branched chain fatty acids. J. Anim. Physiol. Anim. Nutr. 88:401-411.

Weimer, P. J., G. C. Waghorn, C. L. Odt, and D. R. Mertens. 1999. Effect of diet on population of three species of ruminal cellulolytic bacteria in lactating dairy cows. J. Dairy Sci. 82:122-134.

Weisbjerg, M. R., C. F. Børsting, and T. Hvelplund. 1992. The influence of tallow on rumen metabolism microbial biomass synthesis and fatty acid composition of bacteria and protozoa. Acta Agric. Scand., A Anim. Sci. 42:138-147.

Williams, A. G., and N. H. Strachan. 1984. The distribution of polysaccharide-degrading enzymes in the bovine rumen digesta ecosystem. Curr. Microbiol. 10:215-220. 